\title{
WHEY IN THE INDUSTRY: ENVIRONMENTAL AND VALORIZATION IMPACTS
}

\section{REVIEW ARTICLE}

AMARAL, Danilo de Assis ${ }^{1}$, SILVA, José Augusto Ferreira da ${ }^{2}$

AMARAL, Danilo de Assis. SILVA, José Augusto Ferreira da. Whey in the industry: environmental and valorization impacts. Revista Científica Multidisciplinar Núcleo do Conhecimento. Year 06, Ed. 09, Vol. 01, pp. 41-57. September 2021. ISSN:24480959, Access link in: https://www.nucleodoconhecimento.com.br/environmentalengineering-en/whey, DOI: 10.32749/nucleodoconhecimento.com.br/environmentalengineering-en/whey

\section{ABSTRACT}

Whey is a costly and environmentally harmful co-product. Coming from the activities of dairy industries, especially cheese production, whey cannot be discarded directly into the environment because it has a high content of organic matter, which can become an environmental and economic problem, since its treatment for subsequent disposal is time consuming and laborious. In recent decades, however, much research has been developed in search of viable alternatives for the use of whey, instead of just discarding it. One alternative to this is the valorization of whey. The valorization of whey is, therefore, of great interest for economic-environmental reasons and is essential to meet the requirements of Agenda 2030, especially with regard to ODS 6, 9 and 12 (Drinking Water and Sanitation; Industry, Innovation and Infrastructure; Responsible Consumption and Production, respectively). This article

\footnotetext{
${ }^{1}$ Master's Degree in Environmental Engineering at the Federal Institute of Education, Science and Technology Fluminense (IFFluminense), Campus Macaé, Macaé/RJ, Postgraduate in Production Engineering and Project Management at Faculdade ÚNICA and Graduated in Civil Engineering at Universidade Estácio de Sá.

${ }^{2}$ PhD in Geography from the Universidade Estadual Paulista (UNESP). Professor at the Federal Institute of Education, Science and Technology Fluminense (IFFluminense), Campus Macaé, Macaé/RJ, Brazil.
}

RC: 96244

Available in: https://www.nucleodoconhecimento.com.br/environmental-engineeringen/whey 
sought to present a characterization of the production of whey, through a literature review using bibliometric techniques, in order to highlight some alternatives for the reuse and valorization of whey in the industry and its relationship with the environment and the environmental impacts correlated to the disposal and improper handling. Pointing out industrial sectors that can insert whey in production with a view to sustainability and reduction of environmental impacts. With the review of the selected articles to compose this work, it was possible to identify that the valorization of whey is an excellent alternative that should be implemented in industries and that provides gains in both economic and environmental issues.

Key words: Whey, Valorization, Sustainability.

\section{INTRODUCTION}

The food industry is one of the largest industrial sectors in the world. Even though it is not the one that causes most damage to the environment, food manufacturing and processing can cause damage and major environmental impacts when the pollution generated by this industry is not properly treated.

The high production of the dairy industries, the volumes, the environmental impacts involved, and the nutritional value of the co-products, make it an important subject for valorization. Valorization allows one to explore possibilities for reusing the nutrients in the production of main products, and therefore highlights the potential gains that can be achieved and the minimization of environmental impacts.

Dairy industries, especially those that produce cheese, have supplied large amounts of whey as the main co-product of milk processing into cheese or caseins. Although whey has a high nutritional value and functional properties, it has not had its real value and use in the industries.

Studies show that about $40 \%$ of the whey produced in Brazil is improperly discarded, mainly by small and medium-sized enterprises, becoming a harmful industrial waste

RC: 96244

Available in: https://www.nucleodoconhecimento.com.br/environmental-engineeringen/whey 
to nature that causes a high negative environmental impact, due to the damage it offers to fauna and flora, because its Biochemical Oxygen Decomposition (DBO) is about 100 times higher than that of domestic sewage (HARAGUCHI et al., 2006; ROHLFES et al, 2011; GAJO et al., 2017; NUNES et al., 2018).

It is estimated that to produce $1 \mathrm{~kg}$ of cheese, an average of $10 \mathrm{~kg}$ of raw milk is needed and an average of 9 liters of whey is generated, which is a co-product of high nutritional value and highly harmful to the environment, and above all is not valued or reused by the industry.

The reuse of whey is a topic that has already been debated by several researchers from different areas of knowledge around the world, mainly due to its high nutritional value, which enables its processing and transformation into products with high added value (SLAVOV, 2017; MOR et al., 2018; NUNES et al., 2018).

Whey proteins can be widely used in food formulations due to their nutritional and functional properties. And because it contains essential amino acids and is a source of bioactive peptides, which have health-promoting potential, leading to its use in food supplementation and pharmaceutical products (HARAGUCHI et al., 2006).

And when whey is not reused in the industry, or for animal feed, or when there is no treatment for its subsequent disposal, it is inappropriately discarded in water courses, resulting in environmental impacts.

There are many ways to valorize whey and reuse it in the industry, enabling its use in various segments, such as food, pharmaceuticals, energy, agriculture, among others.

The challenge for dairy industries is to correctly manage the whey produced, and after a theoretical survey the main factors of environmental impact are presented, as well as alternatives for the reuse/valuation of whey as a raw material in the manufacture of new products.

RC: 96244

Available in: https://www.nucleodoconhecimento.com.br/environmental-engineeringen/whey 


\section{LITERATURE REVIEW}

\subsection{ENVIRONMENTAL ASPECTS AND IMPACTS OF BRAZILIAN DAIRY INDUSTRIES}

Before starting the environmental issues of dairy products, it is fundamental to present the definitions of environmental aspects and impacts, in order to obtain a better understanding of the whey disposal problem. According to the NBR ISO 14.001 standard, an environmental aspect is defined as "the element of an organization's activity, products or services that can interact with the environment" (ABNT, 2004).

About environmental impact CONAMA Resolution 001, from January 23, 1986, in its article number 1 defines environmental impact as:

Any alteration of the physical, chemical and biological properties of the environment, caused by any form of matter or energy resulting from human activities that, directly or indirectly, affect: I - the health, safety and welfare of the population; II - the social and economic activities; III - the biot; IV - the aesthetic and sanitary conditions of the environment; $\mathrm{V}$ - the quality of environmental resources.

There are several environmental impacts generated by dairy industries. And the main negative impacts are related or correlated to at least one of the following aspects:

\section{- High water consumption}

High water consumption is directly linked to sanitary quality. This is the natural resource with the greatest use in the sector, and it promotes the guarantee of cleanliness of the work environment (equipment, tools, and facilities), and is directly linked to operations, such as cooling and steam generation.

\section{- Generation of effluents}

RC: 96244

Available in: https://www.nucleodoconhecimento.com.br/environmental-engineeringen/whey 
Characterized by the high concentration of organic matter, the effluents from the dairy industry are the main environmental aspects of the sector. They result mainly from washing and cleaning the fleet that transports milk and products, tanks, machinery and equipment directly involved in the production process, in addition to leaks, spills and inefficient equipment operations, which generate losses in the process and disposal of products and co-products, such as whey;

\section{- High energy consumption}

Refrigerated and air-conditioned environments, lighting, ventilation, and equipment operation are related to the quality assurance of the sector's products, which requires high energy consumption.

\section{- Generation of solid residues}

This aspect is characterized not only in the manufacturing process itself, but throughout the manufacturing context, for example: paper, disposables, packaging, material for physical-chemical and microbiological analysis, among others;

\section{- Atmospheric emissions}

The emission of gases into the atmosphere is directly linked to fuel burning and boiler operations.

In addition to the aspects with polluting potential, mentioned above, the disposal of whey is a waste of nutrients, especially proteinaceous material, considering that on average $55 \%$ of the nutrients in milk are present in whey (ALMEIDA et al., 2001; BUSS AND HENKES, 2014).

The liquid effluent generated by these industries and cheese dairies is considered to be the main responsible for pollution. In many industries of this sector, whey is discarded along with other effluents, which is considered an aggravating factor due to

RC: 96244

Available in: https://www.nucleodoconhecimento.com.br/environmental-engineeringen/whey 
its organic load, making it a highly polluting effluent, especially in the production of small and medium industries, since production is centralized only in the production of cheese (GUEDES et al., 2013; BASSETO et al., 2017)

\subsection{WHEY}

Whey, also known as whey or even cheese whey, is the liquid portion extracted from the clotting process during cheese making. It is considered the main co-product of the dairy industry, because its generated volume is about 90 to $95 \%$ of the volume of milk used for cheese making, and it contains approximately half of the total milk solids, including soluble proteins, salts, and especially lactose. On the industrial side, there are two main types of whey, which are sweet whey and acid whey, classified by their total acidity or by their lactic acid content. Acid whey has a pH of 4.5 to 4.8 and a salt content of $0.8 \%$; sweet whey has a $\mathrm{pH}$ of 5.8 to 6.5 and $0.5 \%$ salts (SGARBIERI 2004; MORRILL et al., 2012; ALVES et al., 2014; NUNES et al., 2018; HAUSJELL et al, 2019).

When not used, whey is considered the most worrying residue due mainly to the lactose and protein present, which makes the rate of organic matter high, and can cause severe environmental impact if released into the environment without prior treatment. (MORRIL et al., 2012; SILVA et al, 2018; PINHO, 2019).

\subsubsection{CHARACTERISTICS (NUTRITIONAL VALUE)}

The characteristics and composition of whey depend on the type of processing and the type of cheese to be produced. On average whey contains, 93\% water and $7 \%$ total solids. Of the whey solids, on average, $73 \%$ is lactose, $14 \%$ protein, $7 \%$ fat, $4 \%$ lactic acid and small amounts of vitamins. The protein fraction, contains, on average $50 \%$ beta-lactoglobulin, $25 \%$ alpha-lactalbumin and $13 \%$ other protein fractions, including immunoglobulins (SILVEIRA et al., 2013; HARAGUCHI et al., 2006)

RC: 96244

Available in: https://www.nucleodoconhecimento.com.br/environmental-engineeringen/whey 


\subsubsection{THE POLLUTING POTENTIAL OF WHEY}

One of the main environmental impacts caused by dairy industries is related to the fate of the whey not used for the manufacture of new products, when released directly into waterways, without any treatment (PEREIRA et al., 2018; SILVA et al., 2015; 2018).

The high polluting power of whey is due to the high amount of organic substances present in its composition represented mainly by proteins and lactose. Thus, when discharged into waterways, whey can cause the destruction of flora and fauna due to biochemical oxygen demand (DBO), which has high concentrations. It is estimated that the DBO of whey is approximately 100 times more than the DBO of domestic sewage.

For this reason, environmental legislation prohibits the disposal of whey without efficient treatment. Law $n^{\circ}$ 9.605, of February 12, 1998, provides for criminal and administrative sanctions derived from conducts and activities that are harmful to the environment, and makes other provisions, provided in its Art. 33:

Causing, through the emission of effluents or the transportation of materials, the perishing of aquatic fauna specimens existing in rivers, lakes, ponds, lagoons, bays or Brazilian jurisdictional waters: Penalty - detention, from one to three years, or a fine, or both, cumulatively. (p 11).

Thus, dairy products agribusinesses must obligatorily perform the treatment of their effluents before final disposal in waterways. Industries in this sector, must follow Resolution No. 430, of May 13, 2011, which provides on the conditions and standards for effluent discharge, complements and amends Resolution No. 357, of March 17, 2005, of the National Council of the Environment - CONAMA (BRASIL, 2011). However, each state in Brazil has its own legal specifications governing standards and conditions for effluent discharge.

RC: 96244

Available in: https://www.nucleodoconhecimento.com.br/environmental-engineeringen/whey 
As the generation of whey is on average nine times the amount by weight of cheese produced, it can be seen that its contribution in the final effluent from dairies is very relevant, both in qualitative and quantitative terms. The treatment of these effluents for small and medium-sized industries is a very challenging issue, because it requires high-cost investments, which makes them end up acting illegally, or wasting this valuable product, whey (SILVA et al., 2015; 2018; PEREIRA et al., 2018).

\subsection{ALTERNATIVES FOR WHEY PROCESSING.}

In the past, whey was not used or was only used in animal feed, such as pigs and cattle, but the knowledge of its composition and technological advances led it to be considered an ingredient of great value for the food and pharmaceutical industry. There are numerous applications for whey, including dairy, pharmaceutical, meat, chocolate, snacks and beverages, dry mixtures (for seasoning), baking etc., (MARTINS et al., 2013; BANASZEWSKA et al., 2014).

\subsubsection{FOOD PRODUCTION AND HEALTH BENEFITS}

Whey can be used as a raw material for other products, or be part of their formulation. In the industry, it is already known to be used in the production of foods such as yogurt, dairy drinks and desserts, some types of cheese, such as ricotta, bakery products, supplements, food for athletes and individuals with dietary restrictions, among other uses. Besides having nutritional properties, whey also has highly significant functional properties that promote health benefits. And due to the functional properties, mainly by the proteins present, these confer to the products better characteristics and provide better quality. (ALMEIDA et al., 2001; TERRA et al., 2009; ROHLFES et al., 2011; GUEDES et al., 2013; SIQUEIRA et al, 2013; ROHLFES et al., 2014; NUNES et al., 2018; BARUKČIĆ, 2019; KOPSAHELIS AND KACHRIMANIDOU, 2019).

RC: 96244

Available in: https://www.nucleodoconhecimento.com.br/environmental-engineeringen/whey 
In figure 1, we can see some applications of whey in the food industry, related to the characteristics that it gives to products and the protein percentage.

Figure 1: Example of whey applications attributed to the characteristics and protein percentage.

\begin{tabular}{|c|c|c|c|}
\hline Feature & Food sector & Protein Percentage & Applications \\
\hline Viscosity & Desserts & 35 & $\begin{array}{c}\text { Chocolates, } \\
\text { Marshmallow, }\end{array}$ \\
\hline $\begin{array}{c}\text { Solubility, Colloidal } \\
\text { Stability }\end{array}$ & Drinks & 35 & $\begin{array}{c}\text { Fortified protein, } \\
\text { isotonic, aerated and } \\
\text { food replacement } \\
\text { beverages; Piña } \\
\text { colada, teas, juices } \\
\text { and yoghurts. }\end{array}$ \\
\hline $\begin{array}{c}\text { Emulsification } \\
\text { Foam Formation }\end{array}$ & Soups, children's & 85 & $\begin{array}{c}\text { Low or zero fat soups, } \\
\text { Sauces and processed } \\
\text { cheeses }\end{array}$ \\
\hline Gelation & Dairy products & 35 & $\begin{array}{c}\text { Icing, Sour Cream, } \\
\text { Whipped Cream, }\end{array}$ \\
\hline Elas ticity & Bakery & 65 & $\begin{array}{c}\text { Yogurt, Frozen } \\
\text { Yogurt, Ice Cream }\end{array}$ \\
\hline Water and fat & Meat Products & 65 & $\begin{array}{c}\text { Brownie, Cake, } \\
\text { Cookies, Bread, }\end{array}$ \\
\hline
\end{tabular}

Source: Alves et al., 2014, adapted from UDESC, 2014.

Embedded foods, such as bologna, when in its manufacturing process had the water replaced by whey, there was no negative influence on the characteristics such as: sensory, $\mathrm{pH}$, color and stability. This is a suitable alternative for the reuse of whey (TERRA et al., 2009; ALVES et al, 2014).

RC: 96244

Available in: https://www.nucleodoconhecimento.com.br/environmental-engineeringen/whey 
Due to its nutritional values, and because it is considered an excellent source of protein, and promotes nitrogen retention, with biological improvement and prevention of metabolic stress of the organs, whey has been widely inserted in the diet of athletes of various modalities and degrees of effort (HARAGUCHI et al., 2006).

There are many studies on the benefits of whey in the human diet, especially for some specific groups, such as obese people, where the essential amino acids of whey proteins benefit the metabolic processes in order to reduce body fat, control blood glucose and insulin, and preserve muscle mass during weight loss (ALMEIDA et al, 2001; SCARBIERI, 2004; OLIVEIRA et al., 2012).

Due to the functional properties of the proteins present in whey, there have been significant improvements in the immune system of patients with HIV virus when they are subjected to a supplementation of protein concentrates and anti-cancer activities in cancer cell cultures, antibacterial and antiviral, anti-ulcer and protection of the cardiovascular system (SGARBIERI, 2004).

The immunomodulatory power of whey proteins is another important functional property, as they play an important role in health promotion, for example in controlling blood pressure and as a cardiac risk-reducing agent (HARAGUCHI et al., 2006).

\subsubsection{INDUSTRIAL PRODUCT DEVELOPMENT AND ENERGY PRODUCTION}

While the use of whey is most visible in the food industry, it is also used in the chemical and energy industries. Lactose is an energy source for microorganisms, so it is possible to use whey as a substrate for fermentation to obtain ethanol, biomass, biogas, lactic acid, etc. (KOSSEVA, 2009; DINIZ et al., 2012; PARACHAR et al., 2016).

RC: 96244

Available in: https://www.nucleodoconhecimento.com.br/environmental-engineeringen/whey 
A very interesting application of whey, is that whey proteins can be used in the manufacture of invisible, biodegradable and even edible packaging, which are thin films used to extend shelf life and ensure food quality (EÇA et al., 2014; SANTOS et al., 2015; RYAN and WALSH, 2016).

Significant efforts are being made worldwide to find ways to use whey to produce value-added products. As whey has high nutritional value and the Lactose present can act as the main carbon source for the growth and formation of various biotechnological processes, ethanol and biogas production becomes a promising and viable alternative, as well as reducing environmental impact, not only by avoiding contamination from the whey, but also by producing clean energy (FLORÊNCIO et al, 2013; MURARI et al., 2013, 2017 and 2019; RODRíGUEZ et al., 2016; PEREIRA et al., 2018; ANTONELLI et al., 2019).

\section{MATERIAL AND METHOD}

This research consists of an exploratory-descriptive research, which sought to outline the main means for valorization of whey in the industry, by means of a systematic review of the literature on the studied subject, sought to outline the main avenues for valorization of whey in the industry. The systematic review, as well as other types of review studies, consists of a research that uses a source of data from the literature on a specific subject, in order to group and consolidate the results of primary studies on the subject. This type of research provides a summary of related evidence, strategies, methods, synthesis and criticism (SAMPAIO and MANCINI, 2007).

The methodological strategy used for the development was the steps presented in figure 2.

RC: 96244

Available in: https://www.nucleodoconhecimento.com.br/environmental-engineeringen/whey 
Figure 2: Steps for the systematic literature review process.

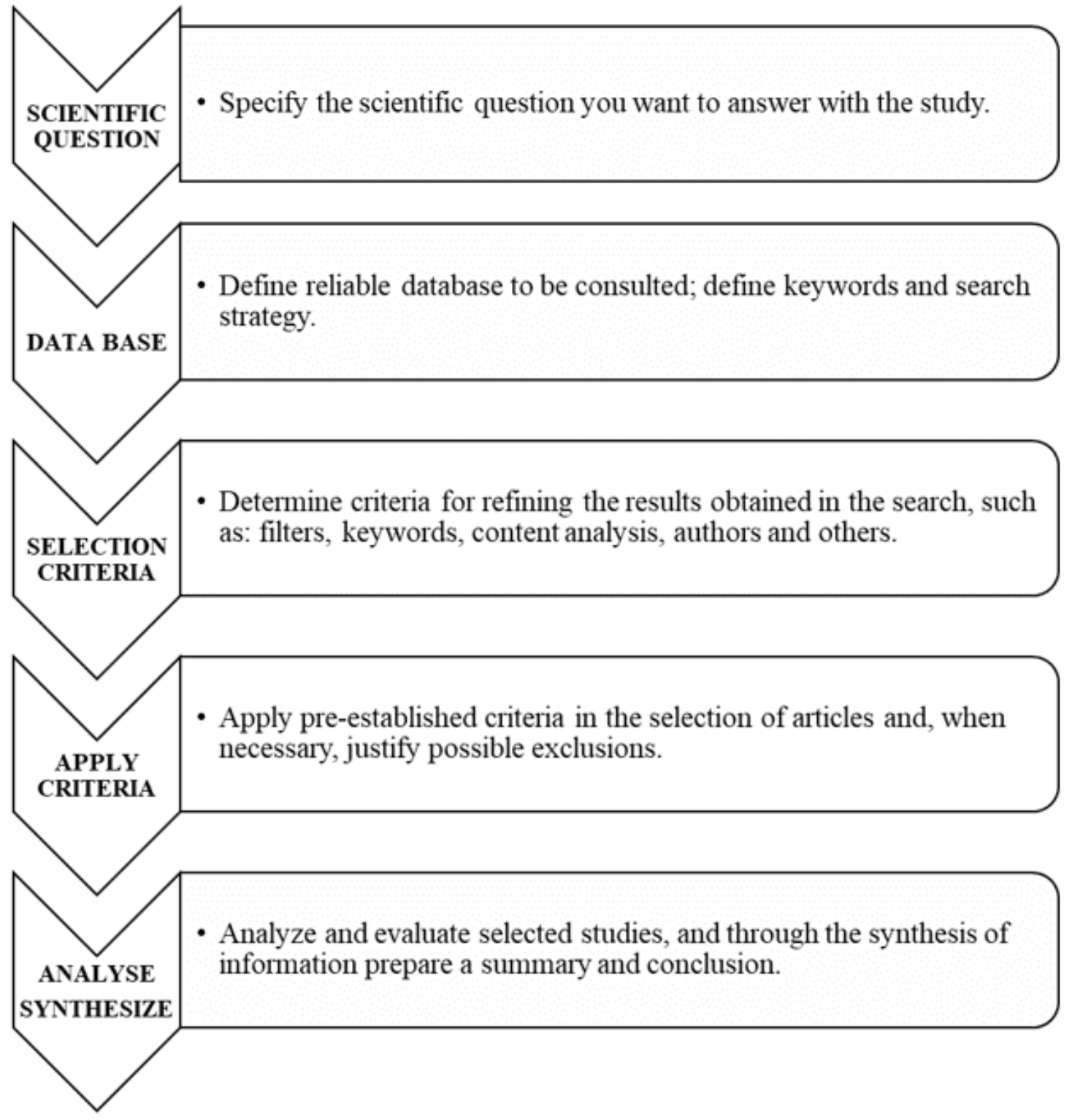

Source: The Authors (2021).

The scientific question is based on the situation that many companies in the dairy industry find themselves in, faced with an increasingly competitive scenario and environmental demands. What to do with whey in the dairy industry?

RC: 96244

Available in: https://www.nucleodoconhecimento.com.br/environmental-engineeringen/whey 
The Capes Periodicals portal < http://www.periodicos.capes.gov.br/> was used as the indexing database. The search was made by subject in an advanced manner, with the objective of obtaining results from several databases, such as Scopus (elsevier) and Scielo. And the search was restricted to peer-reviewed journals.

The search terms used and the strategies applied are listed in figure. The keywords are associated with the terms used in the search for the journals, which are: cheese whey, whey valorization, environment pollution, sustainable.

The selection criteria for the articles were based on the search for the terms sustainability, valorization, management, and environmental impacts, opting for Brazilian research. The application of the criteria was based on the analysis of the article title, abstract, and discussion/conclusion. After selecting the articles of interest, which contributed to the answer to the scientific question, they were analyzed in their full in order to obtain solid content and information.

Figure 3 shows the results of the search based on the strategy used to select the articles that compose this study. When we searched for material using the term whey, we obtained a large number of articles related to it, so by using Boolean operators it was possible to refine the search and reach the selected articles.

RC: 96244

Available in: https://www.nucleodoconhecimento.com.br/environmental-engineeringen/whey 
Figure 3: Search strategy

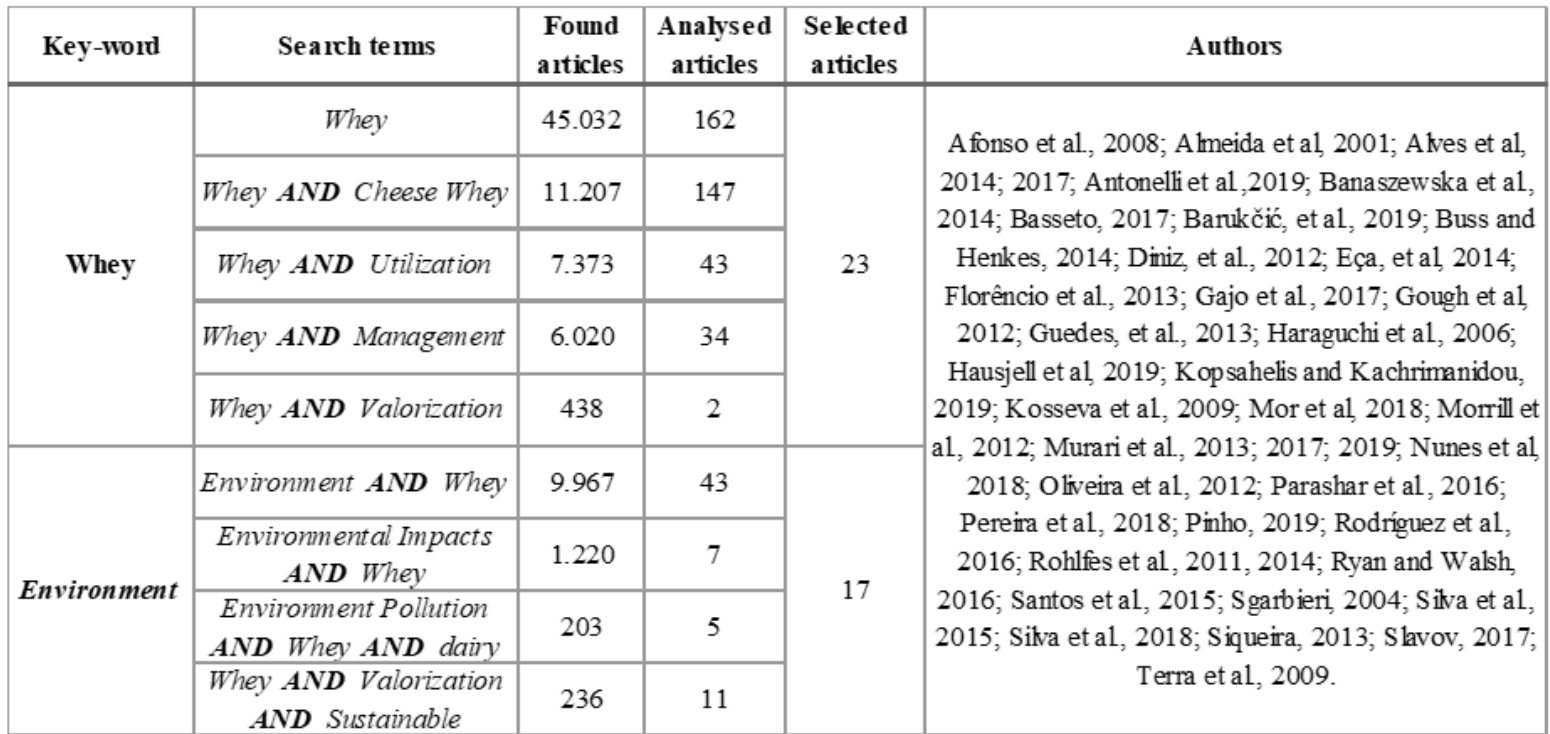

Source: The Authors (2021).

\section{FINAL CONSIDERATIONS}

From the found and analyzed articles, 40 articles were selected to be studied, and to compose this work. These articles, in addition to present the problem which involves the improper disposal and waste of a co-product such as whey, also indicate that it is of fundamental importance to seek alternatives for reuse, mainly due to its nutritional quality and versatility. However, in the current scenario, for small and medium Brazilian dairy industries, economically feasible alternatives for whey recovery are very limited, if considered in isolation. It is important to consider that the solution for the valorization of whey includes issues such as: obtaining quality whey, outflow production, implementation of strategically located units for pre-concentration and forwarding of whey to processing units. This is a challenge, since competitiveness in this sector shows that only companies with efficient production processes and market strength, and with developed environmental programs, can survive and remain productive.

RC: 96244

Available in: https://www.nucleodoconhecimento.com.br/environmental-engineeringen/whey 
Scientific discoveries have shown in recent years that whey is a by-product of the dairy industry of great value, and that its multifunctional properties, especially the proteins presented, have varied applications in various industrial sectors. It is necessary to change the perception that whey is just a waste product; it should be treated as a raw material with nutritional, functional and economic value, which enables value addition along the milk production chain and cost reduction with effluent treatment. And so, the processing of whey will provide a significant improvement in preserving the environment.

Developing sustainable methods for dealing with the whey produced in dairies is of great necessity. There are numerous possibilities in the use of its proteins and various products, however, it is still necessary to explore the potential of whey in the industry. Processes and systems must be developed especially in the emerging fields of bioplastics and biofuel production, where whey can be an ally or even an option in replacing fossil fuels.

\section{REFERENCES}

Afonso, W. DE O.; Biasutti, E. A. R.; Castro, V. M.; Silva, V. D. M.; Silvestre, M. P. C., 2008. Utilização do soro de leite visando reduzir a poluição ambiental: hidrólise pela pancreatina. Revista Tecno-Lógica, Santa Cruz do Sul, v 12, n 2, p 7-16. http://dx.doi.org/10.17058/tecnolog.v12i2.339

Almeida, K. E. DE; Bonassi, I. A.; Roça, R. O., 2001. Características físicas e químicas de bebidas lácteas fermentadas e preparadas com soro de queijo minas frescal. Ciência e Tecnologia de Alimentos, v. 21, n. 2, p. 187-192. http://dx.doi.org/10.1590/S0101-20612001000200012.

Alves, M. P.; Moreira, R. O.; Júnior, P. H. R.; Martins, M. C. F.; Perrone, I. T.; Carvalho, A. F., 2014. Soro de leite: tecnologias para o processamento de

RC: 96244

Available in: https://www.nucleodoconhecimento.com.br/environmental-engineeringen/whey 
coprodutos. Revista do Instituto de Laticínios Cândido Tostes, v. 69, n. 3, p. 212224. https://doi.org/10.14295/2238-6416.v69i3.341

Antonelli, J.; Lindino, C. A.; Azevedo, J. C. R.; Souza, S. N., 2019. Biogas production by the anaerobic digestion of whey. Revista de Ciências Agrárias, $p$. 463- 467. doi: 10.19084/RCA15087

Banaszewska, A.; Cruijssen, F.; Claassen, G. D. H.; Van Der Vorst, J. G. A. J., 2014. Effect and key factors of byproducts valorization: The case of dairy industry. Journal of Dairy Science, v. 97, n. 4, p. 1893-1908. https://doi.org/10.3168/jds.20137283

Basseto, A. L. C., 2017. Contribuições de tecnologias limpas para a indústria de laticínios. $7^{0}$ Congresso Brasileiro de Engenharia de Produção. Ponta Grossa, Paraná.

Barukčić, I.; Jakopovic, K. L.; Bozanic R., 2019. Valorisation of Whey and Buttermilk for Production of Functional Beverages - An Overview of Current Possibilities. Food technology and biotechnology, v. 57, n. 4, p. 448-460. doi: 10.17113/ftb.57.04.19.6460

BRASIL. Conselho Nacional do Meio Ambiente - CONAMA. Resolução no 430, de 13 de maio de 2011. Dispõe sobre condições e padrões de lançamento de efluentes, complementa e altera a Resolução oㅜ 357, de 17 de março de 2005, do Conselho Nacional do Meio Ambiente - CONAMA. Diário Oficial [da] República Federativa do Brasil, Brasília, 16 maio. 2011.

. Lei no 9.605, de 12 de fevereiro de 1998. Dispõe sobre as sanções penais e administrativas derivadas de condutas e atividades lesivas ao meio ambiente, e dá outras providencias. Diário Oficial [da] República Federativa do Brasil, Brasília, DF, 13 fev. 1998.

RC: 96244

Available in: https://www.nucleodoconhecimento.com.br/environmental-engineeringen/whey 
. Lei $n^{\circ} 12.305$, de 2 de agosto de 2010. Institui a Política Nacional de Resíduos Sólidos; altera a Lei no 9.605, de 12 de fevereiro de 1998; e dá outras providências. Diário Oficial [da] República Federativa do Brasil, Brasília, DF, 03 ago. 2010.

. Ministério da Agricultura, Pecuária e Abastecimento - MAPA. Assessoria de Gestão Estratégica. Valor Bruto da Produção Agropecuária (VBP). Disponível em: <http://www.agricultura.gov.br/>. Acesso em: 20 nov. 2019.

Buss, D. A.; Henkes, J. A., 2014. Estudo dos impactos ambientais causados por laticínios com foco no reaproveitamento dos resíduos gerados. Revista Gestão \& Sustentabilidade Ambiental, v. $3, \quad$ n. $2, \quad$ p. 384. http://dx.doi.org/10.19177/rgsa.v3e22014384-395

Diniz, D. DE M.; Druzian, J. I.; Audibert, S., 2012. Produção de goma xantana por cepas nativas de Xanthomonas campestris a partir de casca de cacau ou soro de leite. Polímeros, v. 22, n. 3, p. 278-281. http://dx.doi.org/10.1590/S010414282012005000032

Eça, K. S.; Sartori, T.; Menegalli, F. C., 2014. Films and edible coatings containing antioxidants - a review. Brazilian Journal of Food Technology, v. 17, n. 2, p. 98-112. http://dx.doi.org/10.1590/bjft.2014.017

Florêncio, I. M.; Florentino, E. R.; Silva, F. L. H.; Martins, R. S.; Cavalcanti, M. T.; Gomes, J. P., 2013. Produção de etanol a partir de lactossoro industrial. Revista Brasileira de Engenharia Agrícola e Ambiental, v. 17, n. 10, p. 1088-1092. http://dx.doi.org/10.1590/S1415-43662013001000010.

Gajo, F. F. S., 2017. Diagnóstico da destinação do soro de leite na mesorregião do campo das vertentes - minas gerais. Revista do Instituto de Laticínios Cândido Tostes, v. 71, n. 1, p. 26. https://doi.org/10.14295/2238-6416.v70i1.501

RC: 96244

Available in: https://www.nucleodoconhecimento.com.br/environmental-engineeringen/whey 
Gough, D.; Thomas, J.; Oliver, S., 2012. Clarifying differences between review designs and methods. Systematic Reviews, v. 1, n. 1, p. 28. https://doi.org/10.1186/2046-4053-1-28

Guedes, A. F. L. M.; Machado, E. C. L.; Fonseca, M. C.; Andrade, S. A. C.; Stamford, T. L. M., 2013. Aproveitamento de soro lácteo na formulação de bebidas com frutas e hortaliças. Arq. Bras. Med. Vet. Zootec., v.65, n.4, p.1231-1238. https://doi.org/10.1590/S0102-09352013000400040.

Haraguchi, F. K.; Abreu, W. C.; Paula, H., 2006. Proteínas do soro do leite: composição, propriedades nutricionais, aplicações no esporte e benefícios para a saúde humana. Revista de Nutrição, v. 19, n. 4, p. 479-488. http://dx.doi.org/10.1590/S1415-52732006000400007.

Hausjell, J.; Miltner, M.; Herzig, C.; Limbeck, A.; Saracevic, Z.; Saracevic, E., 2019. Valorisation of cheese whey as substrate and inducer for recombinant protein production in E. coli HMS174 (DE3). Bioresource Technology Reports, v. 8, p. 100340. https://doi.org/10.1016/j.biteb.2019.100340

IBGE - INSTITUTO BRASILEIRO DE GEOGRAFIA E ESTATÍSTICA. Indicadores IBGE - Estatística da Produção Pecuária. Rio de Janeiro: IBGE, 2017.

Sistema IBGE de Recuperação Automática - SIDRA. Pesquisa Pecuária. Disponível em: <http://www.sidra.ibge.gov.br/bda/pecua/>. Acesso em: 15 mar. 2020.

Kopsahelis, N.; Kachrimanidou, V., 2019. Advances in Food and Byproducts Processing towards a Sustainable Bioeconomy. Foods, v. 8 , n. 9, p. 425. doi: 10.1016/j.ijbiomac.2009.09.005

RC: 96244

Available in: https://www.nucleodoconhecimento.com.br/environmental-engineeringen/whey 
Kosseva, M. R., 2009. Use of immobilised biocatalysts in the processing of cheese whey. International Journal of Biological Macromolecules, v. 45, n. 5, p. 437447. doi: $10.3390 /$ foods 8090425

Mor, R. S.; Bhardwaj, A., 2018. SINGH, S. A structured-literature-review of the supply chain practices in dairy industry. Journal of Operations and Supply Chain Management, v. 11, n. 1, p. 14. doi: 10.12660/joscmv11n1p14-25

Morrill, W. B. B.; Rolim, M. M.; Neto, E. B., 2012. Produção e nutrientes minerais de milheto forrageiro e sorgo sudão adubado com soro de leite. Revista Brasileira de Engenharia Agrícola e Ambiental, v. 16, n. 2, p. 182-188. https://doi.org/10.1590/S1415-43662012000200008.

Murari, C. S.; Moraes, D. C.; Bueno, G. F.; Del Bianchi, V. L., 2013. Evaluation of the reduction in pollution of dairy products from whey fermentation in ethanol by yeast Kluyveromyces marxianus 229. Revista do Instituto de Laticínios Cândido Tostes, $\quad$ v. $68, \quad$ n. 393 , p. 42-50. https://doi.org/10.5935/22386416.20130034

Murari, C. S., Moraes, D. C., Del Bianchi, V. L., Silva, B. L., 2017. Influence of Lactose Concentration in Bioethanol Production from Cheese Whey. Acta Scientiarum. Technology, v. 39, n. 5, p. 533. doi: 10.4025/actascitechnol.v39i5.29518 Murari, C. S., Moraes, D. C., Del Bianchi, V. L., Schuina, G. L., Mosinahti, E. F., 2019. Bioethanol Production from Dairy Industrial Coproducts. BioEnergy Research, v. 12, n. 1, p. 112-122. http://dx.doi.org/10.1007/s12155-018-9949-5

Nunes, L. A.; Gerber, J. Z.; Costa, F. P., 2018. O soro do leite, seus principais tratamentos e meios de valorização. Revista em Agronegócio e Meio Ambiente, v. 11, n. 1, p. 301-326. doi: 10.17765/2176-9168.2018v11n1p301-326

RC: 96244

Available in: https://www.nucleodoconhecimento.com.br/environmental-engineeringen/whey 
Oliveira, D. F.; Bravo, C. E. C.; Tonial, I. B., 2012. Soro de leite: um subproduto valioso. Revista do Instituto de Laticínios Cândido Tostes, v. 67, n. 385, p. 64-71. http://dx.doi.org/10.5935/2238-6416.20120025

Parachar, A.; JIN, Y., Mason, B.; Chae, M.; Bressler, D. C., 2016. Incorporation of whey permeate, a dairy effluent, in ethanol fermentation to provide a zero waste solution for the dairy industry. Journal of Dairy Science, v. 99, n. 3, p. 1859-1867. https://doi.org/10.3168/jds.2015-10059

Pereira, C. P.; Prata, D. M.; Santos, L. S.; Monteiro, L. P. C., 2018. Development of eco-efficiency comparison index through eco-indicators for industrial applications. Brazilian Journal of Chemical Engineering, v. 35, n. 1, p. 69-90. http://dx.doi.org/10.1590/0104-6632.20180351s20160370

Pinho, C. L. C. DE, 2019. Produção de ácido lático em meio à base de efluentes da indústria de alimentos por cultura láctea mista imobilizada. Brazilian Journal of Food Technology, v. 22, p. e2018100. https://doi.org/10.1590/1981-6723.10018.

Rodriguez, C. F.; Torres, E. J. M.; Palao, A. M.; Barrios, X. G., 2016. Biological treatments of cheese whey for biogas and hydrogen production. Review. Rev. ION [online]. Vol.29, n.1, pp.47-62. https://doi.org/10.18273/revion.v29n1-2016004.

Rohlfes, A. L. B.; Baccar, N. M.; Oliveira, M. S. R.; Weis, L.; Marquardt, L.; Lopes, L.; Bley, D. E.; Hochscheid, S. L., 2014. Aproveitamento de subproduto de agroindústrias do setor queijeiro para desenvolvimento de produtos alimentícios e redução de impacto ambiental. Tecno-lógica, Santa Cruz do Sul v. 18, n. 1, p. 6. http://dx.doi.org/10.17058/tecnolog.v18i1.4077

Rohlfes, A. L. B.; Baccar, N. M.; Oliveira, M. S. R.; Marquardt, L.; Richards, N. S. P. S.; 2011. Indústrias lácteas: alternativas de aproveitamento do soro de leite como forma de gestão ambiental. Tecno-lógica, Santa Cruz do Sul, v. 15, n. 2, p.79-83. http://dx.doi.org/10.17058/tecnolog.v15i2.2350

RC: 96244

Available in: https://www.nucleodoconhecimento.com.br/environmental-engineeringen/whey 
Ryan, M. P.; Walsh, G., 2016. The biotechnological potential of whey. Reviews in Environmental. Science and Bio/Technology, v. 15, n. 3, p. 479-498. doi: 10.1007/s11157-016-9402-1

Sampaio, R.; Mancini, M., 2007. Estudos de revisão sistemática: um guia para síntese criteriosa da evidência científica. Revista Brasileira de Fisioterapia, v. 11, n. 1, p. 83-89. https://doi.org/10.1590/S1413-35552007000100013

Santos, R. R.; Souza, A. L. R.; Trombete, F. M.; Melo, N. R., 2015. Proteína do soro de leite: Aproveitamento e aplicações na produção de embalagem biodegradável. Revista Verde de Agroecologia e Desenvolvimento Sustentável, v. 10, n. 3, p. 51-58. https://doi.org/10.18378/rvads.v10i5.3033

Sgarbieri, V. C., 2004. Propriedades fisiológicas-funcionais das proteínas do soro de leite. Revista de Nutrição, v. 17, n. 4, p. 397-409, dez. 2004. ISSN 16789865. https://doi.org/10.1590/S1415-52732004000400001

Silva, M. A.; Almeida, N. R. S.; Alemira R. P. R.; Carolino, C. A.; Crispim, L. D., 2015. A problemática ambiental decorrente dos resíduos sólidos gerados no processo produtivo do queijo. Revista Verde de Agroecologia e Desenvolvimento Sustentável, v. 10, n. 2, p. 01, 3. http://dx.doi.org/10.18378/rvads.v10i5.3630

Silva, R. R. DA; Siqueira, E. Q.; Nogueira, I. DE S., 2018. Impactos ambientais de efluentes de laticínios em curso d'água na Bacia do Rio Pomba. Engenharia Sanitaria e Ambiental, v. 23, n. 2, p. 217-228. doi: 10.1590/S1413-41522018138062

Siqueira, A. DE M. O.; Machado, E. DE C. L.; Stamford, T. L. M., 2013. Bebidas lácteas com soro de queijo e frutas. Ciência Rural, v. 43, n. 9, p. 1693-1700. http://dx.doi.org/10.1590/S0103-84782013000900025.

RC: 96244

Available in: https://www.nucleodoconhecimento.com.br/environmental-engineeringen/whey 
Slavov, A. K., 2017. Dairy Wastewaters - General Characteristics and Treatment Possibilities - A Review. Food Technology and Biotechnology, v. 55, n. 1. doi: $10.17113 / \mathrm{ftb} .55 .01 .17 .4520$

Terra, N. N.; Fries, L. L. M.; Milani, L. A. G.; Richards, N. S. P. S.; Rezer, A. P. S.; Backes, A. M., Beulch, S.; Santos, B. A., 2009. Emprego de soro de leite líquido na elaboração de mortadela. Ciência Rural, v. 39, n. 3, p. 885-890. https://doi.org/10.1590/S0103-84782009000300038

Posted: June, 2021.

Approved: September, 2021.

RC: 96244

Available in: https://www.nucleodoconhecimento.com.br/environmental-engineeringen/whey 